\title{
Seroepidemiology and risk factors of Hepatitis $B$ and $C$ virus infections among drug users in Jakarta, Indonesia
}

\author{
Rino A Gani, Unggul Budihusodo, Agus Waspodo, L.A. Lesmana, Irsan Hasan, Nurul Akbar, H.M Sjaifoellah Noer
}

\begin{abstract}
Abstrak
Pasien pengguna obat-obatan sangat meningkat beberapa tahun terakhir ini. Telah dilakukan penelitian untuk mendapatkan gambaran seroepidemiologi infeksi virus hepatitis $B$ dan $C$ pada pelaku penyalahgunaan obat di Jakarta. Data diambil secara konsekutif di RSUPN Cipto Mangunkusumo dan RS Mitra Menteng Abadi, Jakarta, dari semua pasien yang menggunakan narkotika. Sampel serum diperiksa untuk mendeteksi HBsAg (RPHA, Laboratorium Hepatika, Mataram, Indonesia) dan anti-HCV (dipstik, Laboratorium Hepatika, Mataram, Indonesia). Dalam 5 bulan (Maret - Agustus 1999) terdapat 203 kasus pengguna narkotika. Kebanyakan (185/203 kasus, 91,1\%) adalah laki-laki dengan rerata umur 21,2 \pm 4,3 tahun. Rerata umur mulai menggunakan narkotika adalah 18,8 4,0 tahun. Prevalensi Anti-HCV dan HBsAg positif masing-masing adalah 74,9\% (151 kasus) dan 9,9\% (19 kasus) dari seluruh sampel. Pada 168 kasus (84\%), narkotika digunakan dengan cara suntik. Hubungan seksual di luar pernikahan diakui oleh 62 kasus (30,5\%), namun hanya 16 kasus (8\%) yang berganti-ganti pasangan. Tato terdapat pada 32 kasus (15,8 \%). Analisis multivariat menunjukkan bahwa penggunaan suntikan dan tato merupakan faktor risiko yang berkaitan dengan anti-HCV positif. dengan OR masing-masing 9,15 (95\% CI 3,28 - 5,53) dan 13,24 (96\% CI 1,6 - 109,55). Tidak ada satupun faktor risiko medik yang diteliti mempunyai hubungan secara bermakna dengan positivitas HBsAg. Infeksi ganda virus hepatitis $B$ dan virus hepatitis $C$ didapatkan pada 15 kasus $(7,4 \%)$. Kesimpulan penelitian ini adalah: prevalensi infeksi virus hepatitis $B$ dan $C$, serta infeksi ganda kedua virus tersebut di kalangan pelaku penyalahgunaan obat sangat tinggi, dengan tato dan penggunaan suntikan sebagai faktor risiko penularan virus hepatitis C. (Med J Indones 2002; 11: 48-55)
\end{abstract}

\begin{abstract}
The number of drug users is markedly increased in recent times. Data were collected consecutively in Cipto Mangunkusumo Hospital and Mitra Menteng Abadi Hospital in Jakarta. HBsAg were examined using reverse passive hemaglutination assay (RPHA) and anti-HCV with dipstick method; both were from the Laboratorium Hepatika, Mataram, Indonesia. In a 5 month period (March - August 1999) there were 203 cases of drug users. Most of them were male (185 cases or $91.1 \%$ ) with a mean age of $21.2 \pm 4.3$ years. Mean age in starting to use the drug was $18.8 \pm 4.0$ years. The prevalence of anti-HCV and HBsAg positivity were $74.9 \%$ (151 cases) and $9.9 \%$ (19 cases), respectively. The prevalence of double infection was $7.4 \%$ (15 cases). Injection drug users (IDU) were 168 cases (84\%). Extramarital sex was done by 62 cases (30.5\%), but only 16 cases (8\%) with more than one partner. Tattoo was found in 32 cases (15.8\%). Multivariate analysis revealed that IDU and tattoo were the risk factors for anti-HCV positivity, with the OR of $9.15(95 \%$ CI $3.28-5.53)$ and 13.24 (96\% CI 1.6 -109.55), respectively. No significant medical risk factor could be identified for HBsAg positivity. Double infection of HBV and $H C V$ was found in 15 cases $(7.4 \%)$. We concluded that the prevalence of $H B V, H C V$ infection and double infection of HBV - HCV in drug users were high, with tattoo and injection drug usage as risk factors for hepatitis C virus infection. (Med J Indones 2002; 11: 48-55)
\end{abstract}

Keywords: HBsAg, Anti-HCV, tattoo, injection drug users

Marked increase in drug users were noted, recently. The number of drug users who get infected with hepatitis viruses, particularly hepatitis virus B (HBV)

Division of Hepatology, Department of Internal Medicine, Faculty of Medicine, University of Indonesia / Dr. Cipto Mangunkusumo Hospital, Jakarta, Indonesia and $\mathrm{C}(\mathrm{HCV})$ is high, due to their high-risk attitude. Data from other countries had established the high infection rate in this particular group. ${ }^{1,2}$

$\mathrm{HBV}$ and $\mathrm{HCV}$ infections are the most important cause for chronic liver disease. About $80 \%$ of chronic liver disease including liver cirrhosis and liver cancer can be attributable to these viruses. 
HBV transmission may result from accidental inoculation of minute amounts of contaminated blood or body fluids as may occur during medical, surgical or dental procedure using inadequately sterilized syringes and needles, or tattooing or bodypiercing with non-sterile equipment. Accidental inoculation may also occur via shared tooth brushes, razors or any objects that have been contaminated with blood containing the virus. Unlike $\mathrm{HCV}, \mathrm{HBV}$ is more likely to be transmitted by sexual contact and vertical transmission from a mother to her infant. ${ }^{3}$

$\mathrm{HCV}$ is the most prevalent hepatitis virus infection among chronic liver disease patients in several developed countries which have a problem with drug users. Many of them got infected from syringes and needles that they shared with other drug users.

Studies on Jakarta general population in 1994 revealed that the major route of transmission of $\mathrm{HCV}$ was through blood transfusion, while HBV might be through horizontal transmission. Viral transmission among drug users in that time were insignificant due to the very low number of drug users. ${ }^{3,5}$

In this study, we studied the drug users who were admitted into hospitals in Jakarta in order to get the seroepidemiological data of hepatitis B and hepatitis $\mathrm{C}$ virus infection, and to identify the risk factors for viral transmission in drug users.

\section{METHODS}

This study was approved by the Ethical Committee of the Department of Internal Medicine, Faculty of Medicine, University of Indonesia, and was done from early March to end of August 1999, at Cipto Mangunkusumo Central National Hospital and Mitra Menteng Abadi Hospital, in Jakarta. Data were collected consecutively from drug users who were admitted for rehabilitation or drug related complications, and informed consent was given prior to the study. Injection drug users (IDU) were those who injected drugs with syringe and needle into the vein.

Interview of the patients were done by a doctor in a private room of the hospitals, using a questionaire as soon as they were free from drug withdrawal symptoms and urinary test for the drugs was negative.

Demographic data, drug usage (type of drug, the age at the start of drug usage, duration and frequency of drug usage, and medical risk factor data such as: extramarital sexual relationship (yes/no), blood transfusion (yes/no), history of surgery (yes/no), history of jaundice (yes/no), family history of jaundice (yes/no), tattooing (yes/no), body-piercing (yes/no), circumcision (yes/no) and method of drug usage (injection/non-injection) were collected.

The hepatitis B surface antigen (HBsAg) was examined using reverse passive hemaglutination assay (RPHA) kit from Laboratorium Hepatika, Mataram, Indonesia, and antibody of hepatitis $\mathrm{C}$ virus coreprotein (anti-HCV) was examined using anti-HCV dipstick from Laboratorium Hepatika, Mataram, Indonesia. The dipstick method for anti-HCV detection has been shown to have equal sensitivity to commonly used second-generation enzyme-linked immunosorbent assay. ${ }^{5}$

Data were compiled with EpiInfo 6.0 and analyzed using Statistical Product and Service Solutions (SPSS) 9.0 for Windows (University of California Davis). Chisquare or Fisher exact test were applied to compare the results between the two viral infected groups. The odd risk estimation is assumed to be significant if $\mathrm{p}<0.05$. Multivariate analyses using backward logistic regression were done to analyze the risk factors and control the confounding variables for all the variables with $\mathrm{p}<0.2$.

\section{RESULTS}

In the 5 months, there were 203 cases that was entered into the study. There were 65 cases $(32 \%)$ from Cipto Mangunkusumo Hospital, and 138 cases (68\%) from Mitra Menteng Abadi Hospital. Table 1 showed the demographic profile of the drug users in this study.

The prevalence of HBsAg and Anti-HCV among drug users were $9.9 \%$ and $74.9 \%$, respectively. Both $\mathrm{HBsAg}$ and Anti-HCV positivity (double infection) could be detected in 15 patients (7.4\%). No HBsAg nor Anti-HCV could be detected in 48 (23.6\%) of the patients.

Male patients were predominant in this study, they consist of $91.1 \%(185 / 203)$ of all drug users. Almost half of the cases $(49.5 \%)$ was in the age range of 12 20 year. Mean age at the start of using drug was $18.8 \pm$ 4.0 year with mean duration of of $28.3 \pm 19$ months. 
Table 1. The demographic profile of drug users $(n=203)$

\begin{tabular}{|c|c|c|c|c|c|c|c|c|}
\hline & \multicolumn{4}{|c|}{ HBsAg } & \multicolumn{4}{|c|}{ Anti-HCV } \\
\hline & \multicolumn{2}{|c|}{ positive $(n=19)$} & \multicolumn{2}{|c|}{ negative $(n=184)$} & \multicolumn{2}{|c|}{ positive $(n=151)$} & \multicolumn{2}{|c|}{ negative $(n=52)$} \\
\hline & $\mathrm{n}$ & $\%$ & $\mathrm{n}$ & $\%$ & $\mathrm{n}$ & $\%$ & $\mathrm{n}$ & $\%$ \\
\hline : Female & 2 & 10.5 & 16 & 8.7 & 11 & 7.3 & 7 & 13.5 \\
\hline Male & 17 & 89.5 & 168 & 91.3 & 140 & 92.7 & 45 & 86.5 \\
\hline Education : Elementary school & 3 & 15.8 & 49 & 26.6 & 35 & 23.2 & 17 & 32.7 \\
\hline Junior High School & 14 & 73.7 & 120 & 65.2 & 103 & 68.2 & 31 & 59.6 \\
\hline Senior High School & 1 & 5.3 & 11 & 6.0 & 9 & 6.0 & 3 & 5.8 \\
\hline University & 1 & 5.3 & 4 & 2.2 & 4 & 2.6 & 1 & 1.9 \\
\hline Marital status: Married & 1 & 5.3 & 20 & 10.9 & 14 & 9.3 & 7 & 13.5 \\
\hline Not married & 18 & 94.7 & 164 & 89.1 & 137 & 90.7 & 45 & 86.5 \\
\hline Age group : 12 - 15 year & 2 & 10.5 & 11 & 6.0 & 8 & 5.3 & 5 & 9.6 \\
\hline $16-20$ year & 8 & 42.1 & 73 & 39.7 & 58 & 38.4 & 23 & 44.2 \\
\hline $21-25$ year & 4 & 21.1 & 62 & 33.7 & 49 & 32.5 & 17 & 32.7 \\
\hline $26-30$ year & 3 & 15.8 & 27 & 14.7 & 23 & 15.2 & 7 & 13.5 \\
\hline$>30$ year & 2 & 10.5 & 11 & 6.0 & 13 & 8.6 & 0 & 0 \\
\hline
\end{tabular}

There were no significant difference in mean age between the HBsAg or Anti-HCV positive groups, although $\mathrm{HBsAg}$ positive group tended to be younger $(17.8 \pm 2.6)$ than Anti-HCV positive group (27.6 \pm 21.6). HBsAg positivity was more prevalent in the 16 20 years age group, as were Anti-HCV positivity. However, the number of the positive cases decreased in the age group of more than 25 years in both infections. The HBsAg positive and negative cases were not significantly different in terms of sex, education, marital status and age group. This is also observed between Anti-HCV positive and negative cases.

Table 2. showed the association of drug usage in term of type of drugs, duration and frequency of drug usage with $\mathrm{HBsAg}$ and Anti-HCV positivity. The duration of drug usage were not significantly associated with HBsAg nor Anti-HCV positivity. The higher the frequency of drug usage showed bigger percentage of positivity for HBsAg and Anti-HCV, but the association was not statistically significant.

Table 2. The association of drug usage with HBsAg and Anti-HCV positivity

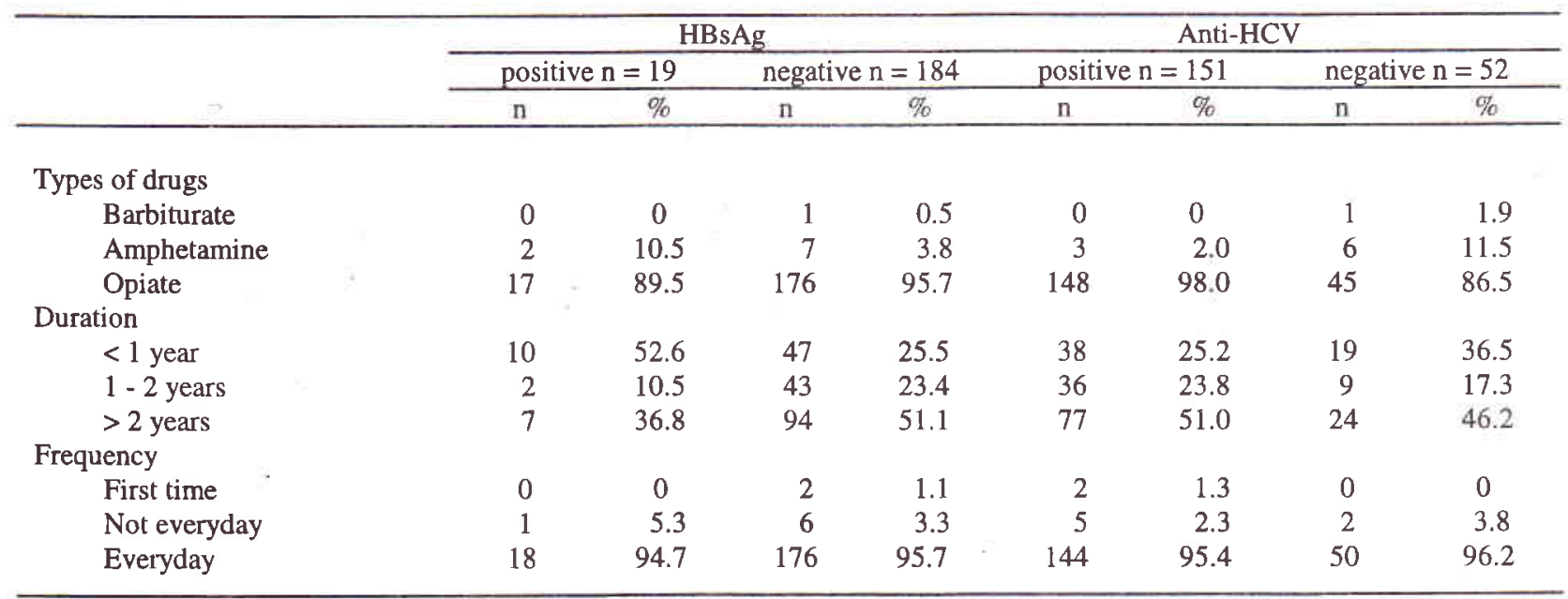

HBsAg : hepatitis B surface antigen

Anti-HCV : antibody to hepatitis C virus 
Opiate was abused in a total of 193 cases $(94.8 \%)$. Type of drug was significantly associated with antiHCV positivity, where opiate was used by 148 of 151 patients $(98 \%)$ with Anti-HCV positive compared to 45 of 52 patients $(86.5 \%)$ with anti-HCV negative. Most patients with HBsAg positive (89.5\%) also used opiate, but there was no significant difference in type of drug, duration and frequency of drug usage between HBsAg positive and negative cases.
Univariate analysis of the medical risk factors for transmission of hepatitis $B$ and $C$ virus were shown in table 3 and 4 . Extramarital sex were practiced by 62 cases $(30.5 \%)$, but only in 16 cases $(8 \%)$ with more than one partner. Furthermore, prevention had been taken for save sex. Tattoos were found in 32 cases (15.8\% of all patients), but HBsAg was positive in only 2 cases $(6.2 \%)$, while Anti-HCV positive was in 31 cases $(96.9 \%)$.

Table 3. Some medical risk factors for HBsAg positivity in drug users $(n=203)$

\begin{tabular}{|c|c|c|c|c|c|c|c|}
\hline & & & & & & & \\
\hline & & & & & & Crude & $95 \%$ Confidence \\
\hline & & $n$ & $\%$ & $n$ & $\%$ & & \\
\hline Extramarital sex & no & 15 & 78.9 & 126 & 68.5 & Ref. & \\
\hline & yes & 4 & 21.1 & 58 & 31.5 & 1.50 & $0.61-3.67$ \\
\hline Tattoo & no & 17 & 89.5 & 154 & 83.7 & Ref. & \\
\hline & yes & 2 & 10.5 & 30 & 16.3 & 1.55 & $0.40-5.98$ \\
\hline Surgery & no & 18 & 94.7 & 167 & 90.8 & Ref. & \\
\hline & yes & 1 & 5.3 & $\cdot 17$ & 9.2 & 1.76 & $0.25-12.47$ \\
\hline Body piercing & no & 12 & 63.2 & 114 & 62.0 & Ref. & \\
\hline & yes & 7 & 36.8 & 70 & 38.0 & 1.03 & $0.56-1.91$ \\
\hline Transfusion & no & 19 & 100 & 181 & 98.4 & & \\
\hline & yes & 0 & 0 & 3 & 1.6 & NA & NA \\
\hline Family history of & no & 19 & 100 & 173 & 94.0 & & \\
\hline jaundice & yes & 0 & 0 & 11 & 6.0 & NA & NA \\
\hline Drink alcohol & no & 18 & 94.7 & 164 & 89.1 & Ref. & \\
\hline & yes & 1 & 5.3 & 20 & 10.9 & 2.07 & $0.29-14.55$ \\
\hline Circumcision & no & 3 & 15.8 & -24 & 13.0 & Rer. & \\
\hline & yes & 16 & 84.2 & 160 & 87.0 & 0.98 & $0.85-1.13$ \\
\hline Method of drug u & age & & & & & & \\
\hline non-inje & tion & 4 & 21.1 & 31 & 16.8 & Ref. & \\
\hline inje & tion & 15 & 78.9 & 153 & 83.2 & 1.05 & $0.83-1.34$ \\
\hline
\end{tabular}

HBsAg : hepatitis B surface antigen

NA :not applicable 
Table 4. Some medical risk factors for Anti-HCV positivity in drug users $(n=203)$

\begin{tabular}{|c|c|c|c|c|c|c|c|}
\hline & & \multicolumn{6}{|c|}{ Anti-HCV } \\
\hline & & \multicolumn{2}{|c|}{ Positive } & \multicolumn{2}{|c|}{ Negative } & \multirow[t]{2}{*}{ Crude OR } & \multirow{2}{*}{$\begin{array}{c}95 \% \text { Confidence } \\
\text { Interval }\end{array}$} \\
\hline & & $\mathrm{n}$ & $\%$ & $\mathrm{n}$ & $\%$ & & \\
\hline Extramarital sex & $\begin{array}{l}\text { no } \\
\text { yes }\end{array}$ & $\begin{array}{c}113 \\
38\end{array}$ & $\begin{array}{l}74.8 \\
25.2\end{array}$ & $\begin{array}{l}28 \\
24\end{array}$ & $\begin{array}{l}53.8 \\
46.2\end{array}$ & $\begin{array}{l}\text { Ref. } \\
0.72\end{array}$ & $0.55-0.94$ \\
\hline Tattoo & $\begin{array}{l}\text { no } \\
\text { yes }\end{array}$ & $\begin{array}{r}120 \\
31\end{array}$ & $\begin{array}{l}79.5 \\
20.5\end{array}$ & $\begin{array}{r}51 \\
1\end{array}$ & $\begin{array}{r}98.1 \\
1.9\end{array}$ & $\begin{array}{l}\text { Ref. } \\
1.23\end{array}$ & $1.13-1.35$ \\
\hline Surgery & $\begin{array}{l}\text { no } \\
\text { yes }\end{array}$ & $\begin{array}{c}138 \\
13\end{array}$ & $\begin{array}{c}91.4 \\
8.6\end{array}$ & $\begin{array}{c}47 \\
5\end{array}$ & $\begin{array}{c}90.4 \\
9.6\end{array}$ & $\begin{array}{l}\text { Ref. } \\
0.99\end{array}$ & $0.89-1.09$ \\
\hline Body piercing & $\begin{array}{l}\text { no } \\
\text { yes }\end{array}$ & $\begin{array}{l}86 \\
65\end{array}$ & $\begin{array}{l}57.0 \\
43.0\end{array}$ & $\begin{array}{l}40 \\
12\end{array}$ & $\begin{array}{l}76.9 \\
23.1\end{array}$ & $\begin{array}{l}\text { Ref. } \\
1.35\end{array}$ & $1.10-1.66$ \\
\hline Transfusion & $\begin{array}{l}\text { nо } \\
\text { yes }\end{array}$ & $\begin{array}{c}150 \\
1\end{array}$ & $\begin{array}{c}99.3 \\
0.7\end{array}$ & $\begin{array}{c}50 \\
2\end{array}$ & $\begin{array}{c}96.2 \\
3.8\end{array}$ & $\begin{array}{l}\text { Ref. } \\
0.97\end{array}$ & $0.92-1.02$ \\
\hline $\begin{array}{l}\text { Family history of } \\
\text { jaundice }\end{array}$ & $\begin{array}{l}\text { no } \\
\text { yes }\end{array}$ & $\begin{array}{c}141 \\
10\end{array}$ & $\begin{array}{c}93.4 \\
6.6\end{array}$ & $\begin{array}{c}51 \\
1\end{array}$ & $\begin{array}{c}98.1 \\
1.9\end{array}$ & $\begin{array}{l}\text { Ref. } \\
1.05\end{array}$ & $0.99-1.11$ \\
\hline Drink alcohol & $\begin{array}{l}\text { no } \\
\text { yes }\end{array}$ & $\begin{array}{c}134 \\
17\end{array}$ & $\begin{array}{l}88.7 \\
11.3\end{array}$ & $\begin{array}{c}48 \\
4\end{array}$ & $\begin{array}{c}92.3 \\
7.7\end{array}$ & $\begin{array}{l}\text { Ref. } \\
1.04\end{array}$ & $0.94-1.15$ \\
\hline Circumcision & $\begin{array}{l}\text { no } \\
\text { yes }\end{array}$ & $\begin{array}{c}21 \\
130\end{array}$ & $\begin{array}{l}13.9 \\
86.1\end{array}$ & $\begin{array}{c}6 \\
46\end{array}$ & $\begin{array}{l}11.5 \\
88.5\end{array}$ & $\begin{array}{l}\text { Ref. } \\
0.85\end{array}$ & $0.40-1.80$ \\
\hline $\begin{array}{r}\text { Method of drug u } \\
\text { non-in } \\
\text { in }\end{array}$ & $\begin{array}{l}\text { ige } \\
\text { ection } \\
\text { ction }\end{array}$ & $\begin{array}{r}9 \\
142\end{array}$ & $\begin{array}{r}6.0 \\
94.0\end{array}$ & $\begin{array}{l}26 \\
26\end{array}$ & $\begin{array}{l}50.0 \\
50.0\end{array}$ & $\begin{array}{l}\text { Rel: } \\
8.40\end{array}$ & $4.2-16.72$ \\
\hline
\end{tabular}

Anti-HCV : antibody to hepatitis C virus

IDU were identified in 168 cases $(82.8 \%)$ and 127 cases $(75.6 \%)$ among them had ever shared needle. In IDU, 142 were positive for Anti-HCV (84.5\%), and 15 were HbsAg positive (8.9\%).

Our data showed that there were no medical risk factors (extramarital sex, tattooing, ever had surgery, body piercing, history of transfusion, family history of jaundice, alcohol drinking) that were associated with IbsAg positivity.

Mitivariate analysis of the above mentioned risk ructos revealed that only tattoo (yes/no) and method of vilig usage (injection/non-injection) were risk factors associated with anti-HCV positivity. The model of the relationship of these factors were shown in table 5.

Table 5. Model for Anti-HCV positivity

\begin{tabular}{|c|c|c|}
\hline & OR & $\begin{array}{c}95 \% \text { Confidence } \\
\text { Interval }\end{array}$ \\
\hline \multicolumn{3}{|l|}{ Method of drug usage : } \\
\hline Non-injection & Ref. & \\
\hline Injection & 9.15 & $3.28-25.53$ \\
\hline \multicolumn{3}{|l|}{ Tattoo: } \\
\hline No & Ref. & \\
\hline Yes & 13.24 & $1.6-109.55$ \\
\hline
\end{tabular}

Anti-HCV : antibody to hepatitis $\mathrm{C}$ virus 


\section{DISCUSSION}

This study was done in hospitals where only specific cases were admitted which make it difficult to compare the result to the condition in general population. However, the two hospitals have a different patient characteristics. Most patients admitted to Cipto Mangunkusumo hospital appeared to have medical complications and came from the lower socioeconomic level. On the contrary, those admitted to Mitra Menteng Abadi Hospital were free from complications and came from higher socioeconomic level. Nevertheless, no detailed data about socioeconomic level, and the use of house hold utensils contributing in the transmission of hepatitis viruses could be obtained.

Male patients were predominant in this study and most of them were IDU who used opiate. These characteristics were different from a hospital based study in other country where most of them were non IDU. ' The use of injection in Indonesian drug users may just recently arise and is increasing very fast. They were relatively young (adolescence period) and had started to use the drug in high school. The youngest case of this study was a 12-year-old male who already used opiate by injection with a shared needle. Adolescence is recognized as a period of time where someone has a strong bond to their group of friends and also needs to explore anything including drugs.

In general population, HBsAg positive prevalence was $4 \%,{ }^{4}$ while in the present study, it is $9.9 \%$ which is 2.5 times greater. This study showed that drug users were on high-risk for HBV infection. The prevalence of HBsAg positivity among the drug users in this study is higher compared to the western country, but it is about the same compared to the other Asian countries. ${ }^{7,89}$ The reason for this discrepancy is not clear, but it may be associated with the prevalence of HBsAg positivity in the general population.

$\mathrm{HBV}$ and HCV may share the same pathway of transmission such as via body fluid or blood, hence the risk factor for viral transmission may be the same for both viruses. However, some pathway may be effective for $\mathrm{HBV}$, but not for $\mathrm{HCV}$, and vice versa.

Hepatitis B virus transmission in this group of population was not related to the several medical risk factors mentioned above. Another study also found no relationship between the use of syringe or needle and
HBsAg positivity. ${ }^{1}$ In a general population study, only socioeconomic, ethnicity (Chinese) and number of family members were the risk factors for $\mathrm{HBsAg}$ positivity, while medical risk factors such as: blood transfusion, history of jaundice, family history of jaundice and ever had operation were not related to HbsAg positivity. ${ }^{4}$ However, no drug users was included in that study. Risk factors for hepatitis B transmission in drug users has yet to be determined, but horizontal transmission may play a bigger role, because age-specific prevalence in this study showed bigger percentages of HBsAg positivity in the age range of $16-25$ compared to the younger age group. Since inter-relation within drug users in daily life is very close, this can be the reason for the transmission of hepatitis $\mathrm{B}$ virus among them. Therefore, a more detailed study in the behavior of drug users is needed.

In this study, extramarital sex was practiced by one third of the drug users. Having sex with IDU is reported as a risk factor for $\mathrm{HBV}$ and $\mathrm{HCV}$ transmission, ${ }^{7}$ although this study could not confirmed it. This may be due to cases, who confessed to have sexual intercourse, and gave the data about the number of intercourse done, or the number of sexual partner, that was not suficient to uncover the relationship between those variables with $\mathrm{HBsAg}$ or Anti-HCV positivity. Nevertheless, this study revealed that some drug users practiced unsafe sexual relationship, which together with IDU were also risk factors for other diseases such as HIV. ${ }^{9}$

The prevalence of Anti-HCV positivity among IDU in this study was lower compared to the study on IDU in Kuala Lumpur, Malaysia where $92.5 \%$ of the cases were positive for anti-HCV. ${ }^{10}$ The just recently marked increase of drug users in Indonesia may explain the lower number of $\mathrm{HCV}$ prevalence compared to the prevalence in Malaysia. However, the prevalence of Anti-HCV positivity in this study was higher compared to other countries where anti-HCV prevalence in IDU was $50-75 \% .^{7.811-14}$ This is due to the lack of specific and major public programs to prevent viral transmission among IDU in Indonesia, while in the country where the problem of IDU has already been recognized as a major public problem, several programs have been introduced, such as syringe exchange program or methadone clinic.

In the same age group of the general population in Jakarta ( $12-30$ years), the prevalence of anti-HCV is 
only $0.4 \% .^{15}$ Our data showed that the prevalence of anti-HCV positivity in drug users was $150-200$ fold higher than in general population. Hepatitis $\mathrm{C}$ virus infection is rarely symptomatic. Most $\mathrm{HCV}$ infection occurs as chronic hepatitis which leads to liver cirrhosis in about 20 years. ${ }^{16}$ This can be a substantial problem in the future long after the addiction problem in drug users have been eliminated.

This study also showed that the prevalence of double infection of hepatitis $\mathrm{B}$ and $\mathrm{C}$ was also higher compared to in general population where only $0.2 \%$ cases were positive for both anti-HCV and HBsAg. ${ }^{4}$ Double infection of $\mathrm{HBV}$ and $\mathrm{HCV}$ is one of the factors that may lead to the development of chronic liver disease. Liver disease is usually more severe in double infection cases, and the risk of developing hepatocellular carcinoma ( $\mathrm{HCC})$ are much higher than patients infected by either single virus alone. ${ }^{17,18}$

The risk factors for anti-HCV positivity among drug users in this study were injection drug usage and having tattoo. Injection drug usage was also reported as one of the risk factors for hepatitis $C$ virus transmission among drug users in other study. ${ }^{19,20}$ Our findings is not in agreement with the study in the general population, where the risk factors for anti$\mathrm{HCV}$ positivity were age and blood transfusion. ${ }^{4}$ The reasons for the difference might be the small number of cases who ever had blood transfusion, and the relatively narrower range of patients' age in this study compared to the study in general population.

Tattoo in the general population study was not associated with anti-HCV positivity. ${ }^{5}$ This might be due to the relatively smaller number of people who had tattoo in that study compared to our data. Tattooing is often applied by the drug users' companion, who in most circumstances were'also a drug user, without enough knowledge of sterility to prevent the transmission of microorganism. Tattoo had also been reported as one of the risk factor for hepatitis $\mathrm{C}$ virus infection in drug users in a study in an Asian country. ${ }^{21}$ Even in the population of non injection drug users, having a tattoo was associated with anti-HCV positivity. ${ }^{19}$

Several studies in general population conducted $4-5$ years ago could identify only a very small number of drug users. ${ }^{4.5}$ This group of population have been increased several folds recently. Therefore, the number of people who get infected with HBV and
$\mathrm{HCV}$ in general population will increase rapidly. It can be expected that in young people $(<30$ years old $)$ the prevalence of hepatitis $B$ and $C$ virus infection will be increased. Furthermore, the double infection of HBV and $\mathrm{HCV}$ was also high, and this would be a bad prognosis for the progression to chronic liver disease. In the future, the number of people with chronic liver disease in this area may be increased due to this reason.

Experience in another country showed that drug users, particularly IDU, who began in the recent past got a higher risk to suffer from chronic hepatitis, liver cirrhosis and liver cancer. ${ }^{16,20} \mathrm{~A}$ large population based study should be conducted to clarify this issue.

Preventions for $\mathrm{HBV}$ and $\mathrm{HCV}$ transmission in Indonesia have been already implemented including HBV vaccination and screening of blood donors. Hopefully such measures can minimize both viral transmission through vertical route for $\mathrm{HBV}$ and horizontal route for $\mathrm{HCV}$. However, viral transmission from drug user route may potentially be more important in the future and also need prompt management.

No vaccine has yet been available for the prevention of HCV infection, but studies in this field are still progressing. One candidate is the DNA vaccination which is promising in animal models and shortly can be expected to be studied in human.

In conclusion, this study revealed that in drug users the prevalence of $\mathrm{HCV}, \mathrm{HBV}$ and double infection of these two viruses are high and much higher compared to the infections in general population. Injected drug usage and tattoo are risk factors for $\mathrm{HCV}$ transmission.

\section{Acknowledgment}

We highly appreciate Prof. Dr. Mulyanto and his staff at Laboratorium Hepatika, Mataram for their help in training of our staff and the generosity in supplying the reagent for HbsAg RPHA and anti-HCV dipstick. Also to Prof. Dr. Dadang Hawari, Dr. Ratna MS, and Dr. Herdiman who were willing to give permission to let their patients participate in this study.

\section{REFERENCES}

1. Maayan S, Shufman EN, Engelhard D, Shouval D. Exposure to hepatitis $\mathrm{B}$ and $\mathrm{C}$ and to HTLV-1 and 2 
among Israeli drug abusers in Jerusalem. Addiction 1994;89(7):869-74.

2. Conry CC, VanRaden M, Gibble J, Melpolder J, Shakil $A O$, Viladomiu $L$ et al. Routes of infection, viremia, and liver disease in blood donors found to have hepatitis $\mathrm{C}$ virus infection. N Engl J Med 1996;334:1691-6.

3. Zuckerman JN, Zuckerman AJ. The epiderniology of hepatitis B. Clin Liver Dis 1999;3 (2):179-87.

4. Nurul Akbar, Bastaman Basuki, Mulyanto, David H Garabrant, Ali Sulaiman, H.M Sjaifoellah Noer. Ethnicity, socioeconomic status, transfusions and risk of hepatitis $B$ and hepatitis C infection. J Gastroentrerol Hepatol 1997; 12:752-7.

5. Wijaya S. Epidemiology of hepatitis B and hepatitis C virus infection in urban area in Jakarta, Indonesia: A hospital and population based study. [Dissertation] Leuven: Catholic University Leuven Belgium; 1996.

6. Mulyanto, Suwignyo S, Tsauri S, Itoh K, Mizui M, Tsuda $\mathrm{F}$ et al. An easy dipstick assay for anti-core antibodies to screen blood donors for hepatitis $\mathrm{C}$ virus viremia. Vox Sang 1996; 70:229-31.

7. Kaur S, Rybicki L, Bacon BR, Golan JL, Rustgi VK, Carey WD. Pertormance characteristics and results of a large-scale screening program for viral hepatitis and risk factors associated with exposure to viral hepatitis B and C: results of the National Hepatitis Screening Survey. National Hepatitis Surveillance Group. Hepatology 1996;24:979-56.

8. Sinyth BP, Keenan E, O'Connor JJ. Bloodborne viral infection in Irish injecting drug users. Addiction 1998;93(11):1649-56.

9. Baozhang $\mathrm{T}$, Kaining Z, Jinxing $\mathrm{K}$, Ruchang X, Ming L, Caixia $Z$ et al. Infection with human immunodeficiency virus and hepatitis viruses in Chinese drug addicts. Epidemiol Infect 1997;119(3):343-7.

10. Duraisamy G. HIV and hepatitis $B, C$ and D markers in intravenous drug addicts screen in 1992. In : Proceeding $9^{\text {th }}$ Biennial Scientific Meeting Asian Pacific Association for the Study of the Liver; January 26-29, 1994. Kuala Lumpur, Malaysia. Kuala Lumpur: Asian Pacific Association for the Study of the Liver; 1994. p.429-34.

11. Lamden KH, Kennedy N, Beeching NJ, Lowe D, Morrison CL, Mallinson H, et al. Hepatitis B and hepatitis
C virus infections: risk factors among drug users in Northwest England. J Infect 1998;37(3):260-9.

12. Galeazzi B, Tufano A, Barbierato E, Bortolotti F. Hepatitis $C$ virus infection in Italian intravenous drug users: epidemiological and clinical aspects. Liver 1995; 15(4):209-12.

13. Anand CM, Fonseca K, Walle RP, Powell S, Williams M Antibody to hepatitis $\mathrm{C}$ virus in selected groups of a Canadian urban population. Int J Epidemiol 1992; 21(1):142-5

14. Patti AM, Santi AL, Pompa MG, Giustini C, Vescia N, Mastroeni I, et al. Viral hepatitis and drugs: a continuing problem. Int J Epidemiol 1993;22(1):135-9.

15. Nurul Akbar, Fumio Tsuda, Bastaman Basuki, Hiroaki Okamoto, Ali Sulaiman, HM Sjaifoellah Noer, et al. The prevalence of $\mathrm{GB}$ virus $\mathrm{C}$, risk factors and its relationship with other viruses in a general population in Jakarta, Indonesia. Hepatol Res 1999;13:193-204.

16. Ke-Qin Hu, Myron J Tong. The long-term outcomes of patients with compensated hepatitis $C$ virus-related cirrhosis and history of parenteral exposure in the United States. Hepatology 1999;29(4):1311-6.

17. Fong TL, Di Bisceglie AM, Waggoner JG, Banks SM, Hoofnagle JH. The significance of antibody to hepattis $\mathrm{C}$ virus in patients with chronic hepatitis B. Hepatology 1991;14:64-7.

18. Benvegnu L, Fattovich G, Noventa F, Tremolada F, Chemello L, Cecchetto A, et al. Concurrent hepatitis B and $C$ virus infection and risk of hepatocellular carcinoma in cirrhosis. A prospective study. Cancer 1994;74:2442.

19. Balasekaran $R$, Bulterys $M$, Jamal MM, Quinn PG, Johnston DE, Skipper B, et al. A case-control study of risk factors for sporadic hepatitis $C$ virus infection in the southwestern United States. Am J Gastroenterol 1999; 94:1341-6.

20. Alter MJ, Kruszon-Moran D, Nainan OV, McQuillan G, Gao F, Moyer LA et al. The prevalence of hepatitis C virus infection in the United States 1988 through 1994. N J Engl Med 1999;341:556-62.

21. Chang CJ, Ko YC, Liu HW. Seroepidemiology of hepatitis $\mathrm{C}$ virus infection among drug abusers in southern Taiwan. J Formos Med Assoc 1998;97(12):826-9. 